\title{
Labrys methylaminiphilus sp. nov., a novel facultatively methylotrophic bacterium from a freshwater lake sediment
}

Correspondence

Ludmila Chistoserdova milachis@u.washington.edu

\author{
Jonathan A. Miller, ${ }^{1}$ Marina G. Kalyuzhnaya, ${ }^{2}$ Emma Noyes, ${ }^{3} \dagger$ \\ Jimmie C. Lara, ${ }^{1}$ Mary E. Lidstrom ${ }^{1,2}$ and Ludmila Chistoserdova ${ }^{2}$ \\ 1,2Departments of Microbiology ${ }^{1}$ and Chemical Engineering ${ }^{2}$, University of Washington, Seattle, \\ WA 98195, USA
}

${ }^{3}$ Omak High School, Omak, WA 98841, USA

A new bacterial isolate from a methylamine enrichment culture is described, representing a novel species of facultatively methylotrophic bacteria. The non-motile bacterium is Gram-negative, replicates by budding and does not form endospores. The isolate utilizes methylated amines, as well as a variety of monosaccharides, disaccharides, amino acids, organic acids, aromatic compounds and alcohols as substrates, but does not utilize methanol. Growth factors are not required, although yeast extract stimulates growth. The major components of the fatty acid profile are $\mathrm{C}_{18: 1} \omega 7 c, \mathrm{C}_{19: 0}$ cyclo and $\mathrm{C}_{16: 0}$. The dominant cellular phospholipids are phosphatidyl acid, phosphatidylcholine and phosphatidylethanolamine. The $\mathrm{G}+\mathrm{C}$ content of the DNA is $65 \cdot 7 \pm 0.3$ mol\%. $16 \mathrm{~S}$ rRNA gene-based phylogenetic analysis revealed that the novel isolate belongs to the $\alpha$-Proteobacteria and is closely related to the only representative of the genus Labrys, Labrys monachus (97.4\% sequence similarity). However, the level of DNA-DNA relatedness with $L$. monachus is less than $3 \%$, justifying the placement of this isolate into a novel species of the genus Labrys. The name Labrys methylaminiphilus sp. nov. is proposed (type strain $\mathrm{JLW}_{10}{ }^{\top}=\mathrm{ATCC}^{\mathrm{BAA}}-1080^{\top}=\mathrm{DSM} 16812^{\top}$ ).

Methylotrophs are a group of bacteria capable of metabolizing compounds containing no carbon-carbon bonds as sole sources of carbon and energy. These bacteria are ubiquitous in the biosphere and have been isolated from a wide variety of natural habitats including plants, soils and freshwater and marine sediments (Anthony, 1982). Methylotrophs play an important role in biogeochemical cycling and possess a potential for use in bioremediation (Pol et al., 1994; De Marco et al., 2004). We are studying a specific habitat that is rich in methylotrophic activity: the sediment of Lake Washington at a depth of about $60 \mathrm{~m}$ (Kuivila et al., 1988; Costello \& Lidstrom, 1999). Until recently, research at this site has focused primarily on methanotroph populations (Auman et al., 2000; Costello \& Lidstrom, 1999) and no survey of broader methylotroph presence has been

Published online ahead of print on 14 January 2005 as DOI 10.1099/ ijs.0.63409-0.

tPresent address: Department of Microbiology, University of Washington, Seattle, WA 98195, USA.

Abbreviation: $\mathrm{MH}_{4} \mathrm{FDH}$, methylenetetrahydrofolate dehydrogenase.

The GenBank/EMBL/DDBJ accession number for the nearly complete sequence of the $16 \mathrm{~S}$ rRNA gene of Labrys methylaminiphilus $\mathrm{JLW} 10^{\top}$ is AY766152 conducted. This study focused on enrichment, isolation and taxonomic description of methylamine-utilizing bacteria from Lake Washington sediment. One of these isolates, a novel facultative methylotroph, is described.

Sediment samples were collected on 21 July 2003, off the RV Clifford Barnes from a $63 \mathrm{~m}$-deep site in Lake Washington, Seattle, WA, USA $\left(47^{\circ} 38 \cdot 075^{\prime} \mathrm{N} 122^{\circ} 15 \cdot 993^{\prime} \mathrm{W}\right)$ using a box core that allowed collection of undisturbed sediment. Sediment cores were taken to a depth of approximately $20 \mathrm{~cm}$ and subsectioned into layers approximately $1.5 \mathrm{~cm}$ thick. Samples were transported to the laboratory on ice and used immediately. One millilitre samples of the upper $1.0 \mathrm{~cm}$ of the sediment cores were inoculated into $250 \mathrm{ml}$ flasks containing $50 \mathrm{ml} 0 \cdot 2 \times$ salts medium (Harder et al., 1973) supplemented with $0.01 \%$ methylamine (w/v) and were incubated for 6-8 days at room temperature with shaking (125 r.p.m.). In subsequent enrichments, $10 \mathrm{ml}$ of the previous enrichment culture were diluted $1: 4$ (to a total of $50 \mathrm{ml}$ ) in the same medium, with the methylamine concentration increased to $0 \cdot 2 \%$. Flasks were incubated at room temperature with shaking for 3-5 days. Strain JLW $10^{\mathrm{T}}$ was obtained as a colony after the third enrichment culture was plated onto a solid medium $(0 \cdot 2 \times$ salts medium solidified by $1 \cdot 8 \%$ Bacto agar, supplemented with $0 \cdot 2 \%$ 
methylamine) and incubated at room temperature for 1 week. The isolate was further purified by triplicate streaking on solid medium. The purity of the culture was monitored by microscopy and by restriction fragment length polymorphism (RFLP) analysis of 16S rRNA genes, obtained by PCR amplification of DNA from either a single colony or from $5 \mathrm{ml}$ of liquid culture as described below. For routine cultivation, a methylamine-supplemented minimal medium (Harder et al., 1973) was used. In addition, the following media were used: MMB medium (DSMZ, medium 628), TGY broth (Murray, 1992) and LuriaBertani medium (Sambrook et al., 1989). For long-term storage, $200 \mu \mathrm{l}$ DMSO was added to $1.8 \mathrm{ml}$ exponentially growing liquid culture and the mixed suspensions were stored at $-80^{\circ} \mathrm{C}$. Labrys monachus DSM $5896^{\mathrm{T}}$, obtained from the DSMZ, was used as a reference strain.

For scanning electron microscopy, cells were washed with double-distilled water and fixed in modified Karnovsky's fixative $(2 \%$ paraformaldehyde, $2.5 \%$ glutaraldehyde, $8 \mathrm{mM} \mathrm{CaCl}_{2}$ in $0 \cdot 1 \mathrm{M}$ cacodylate buffer, $\mathrm{pH} 7 \cdot 4$ ) for $2 \mathrm{~h}$ at $4{ }^{\circ} \mathrm{C}$. Cells were then washed three times for $5 \mathrm{~min}$ with double-distilled water, spotted onto plastic coverslips coated with $1 \%$ poly-L-lysine, dehydrated in a graded series of ethanol to $100 \%$ and subsequently critical-point-dried. Samples were sputter-coated with gold/palladium and viewed with a JOEL, JSM 6300F scanning electron microscope at $15 \mathrm{kV}$. Cells of isolate JLW $10^{\mathrm{T}}$ were Gram-negative, non-motile, capsulated, rod-shaped bacteria, $0 \cdot 7-1 \cdot 0 \mu \mathrm{m}$ wide and $1 \cdot 0-1 \cdot 2 \mu \mathrm{m}$ long (Fig. 1). They appeared as single cells or in pairs. Cells reproduced by budding and did not appear to form cysts or other resting bodies. Capsule formation, observed by electron microscopy, was also visualized with India ink (Pelikan) by light microscopy.

The ability of the isolate to utilize various carbon substrates was tested in basal liquid medium in which methylamine was replaced by one of the following carbon sources: methanol, formate, dimethylamine, trimethylamine,

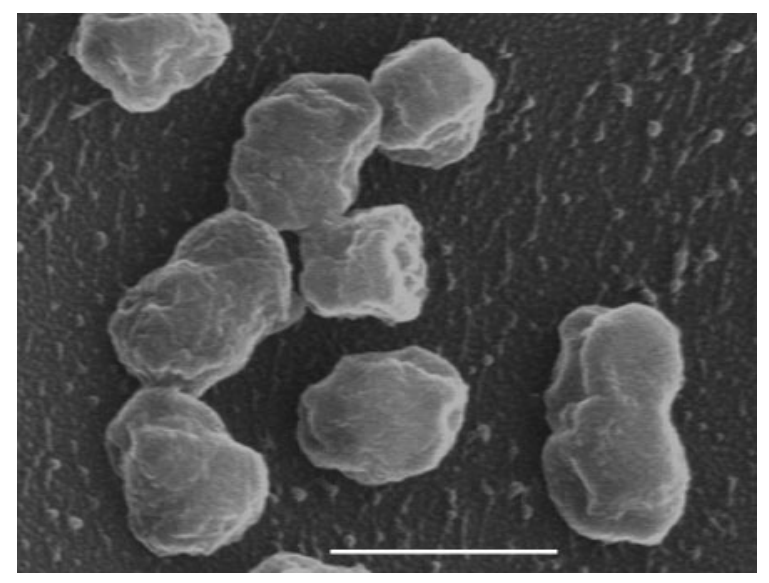

Fig. 1. Scanning electron micrograph of $\mathrm{JLW}_{10} 0^{\top}$ cells. A large amount of capsular material is evident. Bar, $1 \mu \mathrm{m}$. methylsuccinic acid, vanillin, choline, betaine, oxalic acid, sarcosine, acetate, pyruvate, glycolate, citrate, malate, succinate, glucose, maltose, fructose, sucrose, mannitol, ethanol, acetone, toluene, glycerol, serine, valine, alanine, cysteine, asparagine, arginine, aspartate, methionine, histidine, tryptone or yeast extract, at final concentrations of $0 \cdot 01$ and $0 \cdot 1 \%(\mathrm{w} / \mathrm{v})$. Methane utilization was tested using a methane/air $(1: 1, \mathrm{v} / \mathrm{v})$ atmosphere.

Nitrogen sources were tested in nitrogen-free basal liquid medium (as above) in which $\left(\mathrm{NH}_{4}\right)_{2} \mathrm{SO}_{4}$ was replaced with $\mathrm{K}_{2} \mathrm{SO}_{4}$. The following compounds were tested at a concentration of $0 \cdot 1 \%(\mathrm{w} / \mathrm{v}): \mathrm{KNO}_{3}$, methylamine, dimethylamine, trimethylamine, urea, guanidine, glycine, serine, valine, alanine, cysteine, asparagine, arginine, aspartate, methionine, histidine, threonine, proline, glutamate, phenylalanine, tryptophan, peptone and yeast extract. For $\mathrm{N}_{2}$ fixation experiments, the same nitrogen-free basal liquid medium was used. Temperature optima were investigated in TGY medium. pH optima were investigated in the minimal salts medium supplemented with $0 \cdot 1 \%$ methylamine. Due to the poor growth exhibited by the control strain $L$. monachus on methylamine, growth medium for L. monachus was supplemented by $10 \%$ TGY. $\mathrm{NaH}_{2} \mathrm{PO}_{4} / \mathrm{Na}_{2} \mathrm{HPO}_{4}$ at a final total concentration of $0.05 \mathrm{M}$ was used as the buffering system ( $\mathrm{pH}$ range $4 \cdot 0-9 \cdot 6$ ). Culture $\mathrm{pH}$ was monitored at the completion of each experiment, to ensure that no shifts in $\mathrm{pH}$ had occurred. Growth rates were determined by monitoring cell density at $600 \mathrm{~nm}$ using a plate reader (Bioscreen C MBR) or in bulk cultures $(250 \mathrm{ml}$ flasks). Specific growth rates were calculated as the mean of triplicate determinations. The optimal concentration of methylamine for growth was tested using the plate reader at the following concentrations of methylamine (w/v): $0 \cdot 0005$, $0 \cdot 001,0 \cdot 005,0 \cdot 01,0 \cdot 05,0 \cdot 1,0 \cdot 5,1$ and $2 \%$. Desiccation resistance, Voges-Proskauer reaction, oxidation/fermentation catabolism test, nitrite reduction, fluorescent pigment production, urease production, indole production and gelatin hydrolysis were tested according to Smibert \& Krieg (1994). Plate assays were conducted to test ability to degrade agarose and starch. Tests for cellulose and nitrocellulose degradation were conducted in liquid media, using sterile $1 \mathrm{~cm}$ strips of cellulose or nitrocellulose.

Colonies of isolate JLW $10^{\mathrm{T}}$ grown at $30^{\circ} \mathrm{C}$ for 3 days on a basal medium supplemented with methylamine were white, 1-2 $\mathrm{mm}$ in diameter, circular, convex, opaque and butyrous. Specific growth rates in liquid determined using the Bioscreen plate reader were $0.067 \mathrm{~h}^{-1}$ in minimal medium supplemented with methylamine $(0.2 \%)$ and $0.24 \mathrm{~h}^{-1}$ in TGY medium. Comparable rates were obtained in flask experiments (data not shown). Isolate $\mathrm{JLW} 10^{\mathrm{T}}$ grew in the temperature range $10-35^{\circ} \mathrm{C}$, with an optimum at $28-30^{\circ} \mathrm{C}$. The isolate was resistant to desiccation under the conditions tested. Isolate $\mathrm{JLW} 10^{\mathrm{T}}$ grew over a $\mathrm{pH}$ range of $4 \cdot 0-9 \cdot 5$, with an optimum at $\mathrm{pH} 5 \cdot 0-7 \cdot 0$. The optimal concentration of methylamine for growth of $\mathrm{JLW} 10^{\mathrm{T}}$ was $0.05 \%$ and concentrations above $0.5 \%$ were toxic. While 
isolate $\mathrm{JLW} 10^{\mathrm{T}}$ did not require additional growth factors when grown on methylamine, the addition of yeast extract did stimulate growth. In addition to methylamine, the following substrates supported growth of isolate $\mathrm{JLW} 10^{\mathrm{T}}$ as sole sources of carbon and energy: dimethylamine, trimethylamine, methylsuccinic acid, choline, betaine, fructose, glucose, maltose, lactose, mannose, sucrose, sarcosine, succinate, pyruvate, malate, citrate, oxalate, acetate, mannitol, ethanol, acetone, glycerol and all the tested amino acids, with the exceptions of tryptophan and methionine. No growth occurred on methane, methanol, glycolic acid, vanillin, toluene, naphthalene, formaldehyde, DMSO or trichloroethylene. In addition, methylamine, dimethylamine, trimethylamine, urea, ammonium, nitrate, and all tested amino acids served as sole nitrogen sources for growth. Isolate $\mathrm{JLW} 10^{\mathrm{T}}$ did not grow without an added nitrogen source. Accordingly, no product was amplified with primers specific for the nifH gene (Zehr \& McReynolds, 1989), which encodes the Fe-protein of nitrogenase, suggesting that the strain is unable to utilize $\mathrm{N}_{2}$. The isolate hydrolysed agar, agarose, humic acids and cellulose, but not starch or nitrocellulose. Indole and Voges-Proskauer tests were negative. No water-soluble fluorescent pigment was produced on King B medium. Tests for oxidase and catalase were positive. Urease activity was absent. Tests for oxidation of carbohydrates were positive. Glucose was fermented, but not sucrose or lactose. No gas production was observed.

Sensitivity to antibiotics was examined by spreading cells onto TGY agar plates and placing onto them Difco discs that contained the following antibiotics $\left(\mu \mathrm{g} \mathrm{ml}^{-1}\right)$ : gentamicin (10), neomycin (30), streptomycin (10), ampicillin (10), chloramphenicol (30), erythromycin (15), kanamycin (30), nalidixic acid (30), penicillin (10) and tetracycline (30). The effect of antibiotics on cell growth was assessed after 2 weeks. Cells were resistant to kanamycin, ampicillin, erythromycin, nalidixic acid, tetracycline, chloramphenicol and penicillin, but were sensitive to streptomycin, neomycin and gentamicin.

For cell extract preparation, methylamine-grown cells were pelleted by centrifugation at 5000 r.p.m. at $4{ }^{\circ} \mathrm{C}$, resuspended in $1 \mathrm{ml}$ buffer $(25 \mathrm{mM}$ Tris/ $\mathrm{HCl}, 10 \mathrm{mM}$ EDTA, pH $7 \cdot 2$ or $\left.25 \mathrm{mM} \mathrm{KH} \mathrm{PO}_{4} / \mathrm{Na}_{2} \mathrm{HPO}_{4}, \mathrm{pH} 7 \cdot 2\right)$ and disrupted by passage through a French pressure cell at $1 \cdot 2 \times 10^{8}$ Pa. Cell extracts were centrifuged at $20817 \boldsymbol{g}$ for $25 \mathrm{~min}$ at $4{ }^{\circ} \mathrm{C}$ to remove cell debris. Hydroxypyruvate reductase and serine glyoxylate aminotransferase were assayed as described by Goodwin (1990), hexulosephosphate synthase was assayed as described by Shishkina et al. (1976) and phosphoribulokinase and ribulose bisphosphate carboxylase/oxygenase were assayed as described by Tabita (1980). Methylenetetrahydrofolate dehydrogenase $\left(\mathrm{MH}_{4} \mathrm{FDH}\right)$ was assayed as described by Vorholt et al. (1998). Methanol dehydrogenase and methylamine dehydrogenase were assayed according to Anthony \& Zatman (1965) and Eady \& Large (1968), respectively. N-Methylglutamate synthase/ lyase was assayed according to Kimura et al. (1995), with a modification as follows. Formaldehyde formation was followed by coupling to NADPH production in the presence of $\mathrm{MH}_{4} \mathrm{FDH}$. The modified reaction mixture contained the following additional compounds: $0 \cdot 1 \mathrm{mM}$ $\mathrm{NADP}, 3 \mathrm{mM}$ tetrahydrofolate and $1 \mathrm{U} \mathrm{MH}_{4} \mathrm{FDH}$ (all from Sigma). The activity of formate dehydrogenase was measured in the following reaction mixture: $50 \mathrm{mM}$ potassium phosphate buffer, $\mathrm{pH} 7 \cdot 0,1 \mathrm{mM}$ NAD and $20 \mathrm{mM}$ formate. The activity of formaldehyde dehydrogenase was measured in the following reaction mixture: $50 \mathrm{mM}$ potassium phosphate buffer, $\mathrm{pH} 7 \cdot 0,1 \mathrm{mM}$ NAD, $10 \mathrm{mM}$ formaldehyde and $2 \mathrm{mM}$ glutathione. Protein concentration was determined spectrophotometrically (Dawson et al., 2002). The data on enzyme activity measurements are presented in Table 1. No activity was detected for methanol dehydrogenase. Accordingly, PCR amplification of the $m x a F$ gene with specific primers (McDonald \& Murrell, 1997) produced negative results. No methylamine dehydrogenase activity was measured; however, cell extracts possessed $\mathrm{N}$-methylglutamate synthase/lyase activity, the key enzyme for an alternative pathway for methylamine oxidation, the $\mathrm{N}$-methylglutamate pathway (Table 1). No activities were detected for key enzymes of either the ribulose monophosphate cycle for formaldehyde assimilation or for the Calvin-Benson-Bassham cycle, but activities of key enzymes of the serine cycle were present (Table 1). High activity of $\mathrm{MH}_{4} \mathrm{FDH}$ was present, indicating that the tetrahydrofolate-linked pathway may be involved in formaldehyde oxidation/detoxification. One of the most common formaldehyde oxidation pathways in methylotrophs is an analogous pathway linked to tetrahydromethanopterin, the so-called 'archaeal' pathway (Vorholt et al., 1999). We were not able to test for any enzyme activities indicative of this pathway, as tetrahydromethanopterin or its derivatives are not commercially available. However, we were able by PCR to amplify a key gene for this pathway, fae,

Table 1. Enzyme activities in cell extracts of isolate JLW $10^{\top}$

All activity determinations were carried out in triplicate and are given as means $\pm \mathrm{SEM}$ in $\mathrm{nmol} \mathrm{min}^{-1}(\mathrm{mg} \text { protein })^{-1}$. ND, Not detectable.

\begin{tabular}{|lc|}
\hline Enzyme & Activity \\
\hline Methanol dehydrogenase & $\mathrm{ND}$ \\
Methylamine dehydrogenase & $\mathrm{ND}$ \\
N-Methylglutamate synthase/lyase & $82 \pm 10$ \\
Hexulosephosphate synthase & $\mathrm{ND}$ \\
Hydroxypyruvate reductase & $134 \pm 20$ \\
Serine glyoxylate aminotransferase & $188 \pm 30$ \\
Ribulose-1,5-bisphosphate carboxylase/oxygenase & $\mathrm{ND}$ \\
Phosphoribulokinase & $\mathrm{ND}$ \\
Methylenetetrahydrofolate dehydrogenase (NADP) & $47 \pm 5$ \\
Formaldehyde dehydrogenase (GSH) & $109 \pm 12$ \\
Formate dehydrogenase (NAD) & $29 \pm 4$ \\
\hline
\end{tabular}


encoding the formaldehyde activating enzyme (Vorholt et al., 2000). NAD-linked, glutathione-dependent formaldehyde dehydrogenase and formate dehydrogenase activities were also present.

Cellular phospholipid fatty acid (PLFA) analyses were performed by Microbial Insights (http://microbe@microbe. com/). Lipids were recovered using the modified Bligh and Dyer method (White et al., 1979). Extractions were performed using one-phase chloroform/methanol/buffer extractant. Lipids were recovered, dissolved in chloroform and fractionated on disposable silicic acid columns into neutral, glyco- and polar lipid fractions. The polar lipid fraction was trans-esterified with mild alkali to recover the PLFA as methyl esters in hexane. The PLFAs were analysed by gas chromatography with peak confirmation performed by electron impact mass spectrometry (GC/MS). The phospholipids were separated by TLC on Kieselgel 60 F254 plates (Merck) using chloroform/methanol/7 M ammonium hydroxide/water $(65: 25: 3: 1)$ as a solvent system. Iodine stain (Dittmer \& Wells, 1969), Dragendorff spray, ninhydrin reagent (Daniels et al., 1994) and phosphomolybdic acid staining were used for phospholipid identification. Fatty acids found in the polar lipid fraction of isolate $\mathrm{JLW}_{10}^{\mathrm{T}}$ are

Table 2. Differential characteristics of novel strain $\mathrm{JLW}_{1} 0^{\top}$ and related budding and/or facultative methylotrophic bacteria

Taxa: 1, Angulomicrobium (data from Fritz et al., 2004); 2, L. monachus (this study unless indicated); 3, JLW10 ${ }^{\mathrm{T}}$ (this study); 4, Methylorhabdus (Doronina et al., 1995); 5, Methylarcula (Doronina et al., 2000); 6, Aminobacter (Kämpfer et al., 2002); 7, Methylopila (Doronina et al., 1998); 8, 'Methylosulfonomonas' (Holmes et al., 1997). NR, Not reported; -, not detectable; -/+, variable; W, weak.

\begin{tabular}{|c|c|c|c|c|c|c|c|c|}
\hline Characteristic & 1 & 2 & 3 & 4 & 5 & 6 & 7 & 8 \\
\hline Morphology (flagella) & - & $-{ }^{*}$ & - & - & - & + & + & + \\
\hline \multicolumn{9}{|l|}{ Reproduction by: } \\
\hline Budding & + & $+^{*}$ & + & - & - & + & - & - \\
\hline Division & - & $-{ }^{*}$ & - & + & + & - & + & + \\
\hline $\mathrm{pH}$ range & $5 \cdot 2-8 \cdot 0$ & $6 \cdot 0-9 \cdot 5$ & $4 \cdot 0-9 \cdot 5$ & $6 \cdot 0-7 \cdot 0$ & $5 \cdot 5-10$ & NR & $5 \cdot 0-9 \cdot 0$ & $6 \cdot 0-7 \cdot 6$ \\
\hline Optimum pH & $6 \cdot 8-7 \cdot 0$ & $6 \cdot 0-8 \cdot 0$ & $5 \cdot 0-7 \cdot 0$ & $6 \cdot 8-7 \cdot 4$ & $7 \cdot 5-8 \cdot 5$ & $6 \cdot 0-8 \cdot 0$ & $6 \cdot 5-7 \cdot 5$ & $6 \cdot 6$ \\
\hline Temperature range $\left({ }^{\circ} \mathrm{C}\right)$ & $15-40$ & $20-50$ & $10-35$ & $10-45$ & $10-40$ & NR & NR & $20-37$ \\
\hline Optimum growth temperature $\left({ }^{\circ} \mathrm{C}\right)$ & $28-30$ & $28-30$ & $28-30$ & $28-34$ & $29-35$ & $30-37$ & $28-35$ & 30 \\
\hline Catalase & + & + & + & + & + & + & - & + \\
\hline Oxidase & + & + & + & + & + & + & + & $-1+$ \\
\hline Nitrate reduction & - & + & + & + & - & - & + & NR \\
\hline \multicolumn{9}{|l|}{ Hydrolysis of: } \\
\hline Gelatin & NR & - & $\mathrm{W}$ & $\mathrm{W}$ & NR & NR & $\mathrm{W}$ & NR \\
\hline Starch & NR & - & - & $\mathrm{W}$ & NR & NR & $\mathrm{W}$ & NR \\
\hline Agarose & NR & - & + & NR & NR & NR & NR & NR \\
\hline Humic acid & NR & NR & + & NR & NR & NR & NR & NR \\
\hline \multicolumn{9}{|l|}{ Utilization of: } \\
\hline Methanol & - & $\mathrm{W}^{*}$ & - & + & $\mathrm{w}$ & - & + & + \\
\hline Methylamine & NR & $\mathrm{W}^{*}$ & + & + & + & + & + & + \\
\hline Serine cycle & NR & $\mathrm{NR}$ & + & + & + & NR & + & + \\
\hline Calvin cycle & NR & NR & - & - & - & NR & - & - \\
\hline Methylamine dehydrogenase & NR & NR & - & + & - & - & + & NR \\
\hline$N$-Methylglutamate pathway & NR & NR & + & - & + & + & - & NR \\
\hline Major phospholipids $\dagger$ & PG, PEA, PC, PA & PG，PEA，PA $\ddagger$ & PEA & PEA, PG, CL, PC & PEA, PC & NR & PEA, PC & NR \\
\hline \multicolumn{9}{|l|}{ Fatty acids ( $\%$ of total content) } \\
\hline $\mathrm{C}_{16: 0}$ & $5 \cdot 0$ & $19 \cdot 7 \ddagger$ & $17 \cdot 7$ & $15 \cdot 4$ & $0 \cdot 7-1 \cdot 0$ & $4 \cdot 9$ & $2 \cdot 8-5 \cdot 5$ & $7 \cdot 8-8 \cdot 7$ \\
\hline $\mathrm{C}_{18: 1} \omega 7 c / \omega 9 t / \omega 12 t$ & $35 \cdot 8$ & $2 \cdot 9 \ddagger$ & $32 \cdot 8$ & $53 \cdot 6$ & $73 \cdot 4-74 \cdot 2$ & $46 \cdot 4$ & $66 \cdot 0-69 \cdot 6$ & $72 \cdot 4-78 \cdot 7$ \\
\hline $\mathrm{C}_{18: 0}$ & $10 \cdot 5$ & $13 \cdot 0 \ddagger$ & $1 \cdot 7$ & $4 \cdot 0$ & $14 \cdot 7-15 \cdot 6$ & $1 \cdot 5$ & $3 \cdot 6-4 \cdot 5$ & $2 \cdot 0-2 \cdot 3$ \\
\hline $\mathrm{C}_{19: 0}$ cyclo & $24 \cdot 8$ & $40 \cdot 4 \ddagger$ & $49 \cdot 4$ & $16 \cdot 7$ & $0 \cdot 7-1 \cdot 0$ & $13 \cdot 7$ & $8 \cdot 4-15 \cdot 1$ & $14 \cdot 2-28$ \\
\hline $\mathrm{C}_{20: 1} \omega 9$ & $11 \cdot 7$ & $11 \cdot 9 \ddagger$ & - & $0 \cdot 7$ & NR & $0 \cdot 7-1 \cdot 3$ & NR & NR \\
\hline Unknown ECL $18 \cdot 081 / 18 \cdot 063$ & $4 \cdot 1$ & $4 \cdot 2 \ddagger$ & - & NR & NR & $10 \cdot 9-24 \cdot 5$ & NR & NR \\
\hline DNA G $+C$ content $(\mathrm{mol} \%)$ & 68 & $68^{*}$ & $65 \cdot 7$ & $66 \cdot 2$ & $57-61$ & $62-64$ & $66-70$ & 57 \\
\hline
\end{tabular}

${ }^{\star}$ Data from Vasil'eva \& Semenov (1984).

$\dagger$ CL, Cardiolipin; PA, phosphatidic acid; PC, phosphatidylcholine; PEA, phosphatidylethanolamine or phosphatidyldimethylethanolamine; PG, phosphatidylglycerol.

‡Data from Fritz et al. (2004). 
listed in Table 2, together with fatty acids reported in the literature for two reference strains representative of budding bacteria (Labrys and Angulomicrobium) and four reference strains representative of non-pigmented facultatively methylotrophic bacteria (Methylopila, Aminobacter, Methylarcula and Methylorhabdus). The major components of the hydrolysate obtained from methylamine-grown cells of isolate JLW $10^{\mathrm{T}}$ were $\mathrm{C}_{18: 1} \omega 7 c, \mathrm{C}_{19: 0}$ cyclo and $\mathrm{C}_{16: 0}$. The major phospholipids were phosphatidyl acid, phosphatidylcholine and phosphatidylethanolamine.

For DNA extraction, cells (5 g wet weight) were resuspended in $10 \mathrm{ml}$ lysis buffer [10 $\mathrm{mM} \mathrm{NaCl}, 20 \mathrm{mM}$ Tris/ $\mathrm{HCl}, \mathrm{pH} 8 \cdot 0,1 \mathrm{mM}$ EDTA, $100 \mathrm{mg}$ proteinase $\mathrm{K} \mathrm{ml}^{-1}$, $50 \mathrm{mg} \mathrm{RNase} \mathrm{A} \mathrm{ml}^{-1}$ and $0.5 \%$ (w/v) SDS, all from Sigma] and incubated overnight. DNA was purified by phenol/ chloroform extraction and ethanol precipitation (Sambrook et al., 1989). The G $+\mathrm{C}$ content was determined by HPLC separation as described in Tamaoka \& Komagata (1984) and was found to be $65 \cdot 7 \pm 0 \cdot 3 \mathrm{~mol} \%(n=3)$. DNA-DNA hybridization experiments were performed using the competition procedure described by Johnson (1994). DNA $(1 \mu \mathrm{g})$ from isolate $\mathrm{JLW} 10^{\mathrm{T}}$ was labelled with $\left[{ }^{3} \mathrm{H}\right] \mathrm{dCTP}$ (Amersham) using a nick translation kit (Roche). Competitor DNA was digested using a combination of PstI and HindIII (NEB). DNA extracted from L. monachus

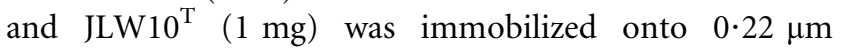
Nytran N membranes (Schleicher \& Schuell) and hybridized with the labelled JLW10 ${ }^{\mathrm{T}}$ DNA (specific activity $5 \times 10^{6}$ d.p.m. $\mathrm{mg}^{-1}$ ), as described by Sambrook et al. (1989). After hybridization, filters were counted in a liquid scintillation counter (Beckman) and the percentage of hybridization was calculated as described by Johnson (1994). Three independent tests were carried out for each pair of DNA preparations. These experiments showed that isolate JLW $10^{\mathrm{T}}$ and L. monachus shared only a low level of DNA-DNA relatedness $(<3 \%)$.

The 16S rRNA gene fragment was amplified as described by Lane (1991) and cloned into the pCR 2.1 vector using the Topo-TA Cloning kit (Invitrogen). DNAs from 30 clones were digested with $A l u \mathrm{I}$ (NEB) and subjected to RFLP analysis, resolved in $2 \%$ agarose gels. Two different RLFP patterns were observed with a frequency of approximately $50 \%$ each. Representatives of each pattern were sequenced. DNA sequencing was carried out using the BigDye 3.1 termination sequencing kit (Applied Biosystems). Gel analyses were performed by the Department of Biochemistry Sequencing Facility at the University of Washington, using an ABI 3700 high-throughput capillary DNA analyser. Plasmids representing the two different RFLP patterns contained inserts of identical DNA, indicating that the two RFLP patterns resulted from two different orientations of the fragment within the cloning vector. For phylogenetic analyses, this sequence was aligned with reference sequences using the CLUSTAL W program (Thompson et al., 1994) and the alignments were manually refined. The PHYLIP package (Felsenstein, 2003) was used to perform neighbour-joining and parsimony analyses, with 1000 bootstrap analyses performed for each method. The two analyses resulted in similar branching patterns. Based on these analyses, the novel isolate fell into the $\alpha$-subclass of Proteobacteria and was most closely related to L. monachus (97.4\% similarity; Fig. 2). Sequences from both isolate $\mathrm{JLW}_{10}{ }^{\mathrm{T}}$ and L. monachus exhibited 86-94\% similarity to those of other known members of the $\alpha$ subclass of Proteobacteria, and both were most closely related to the genera Methylosinus and Methylocystis.

Aerobic, Gram-negative, facultatively methylotrophic bacteria (methylotrophs) comprise a very heterogeneous

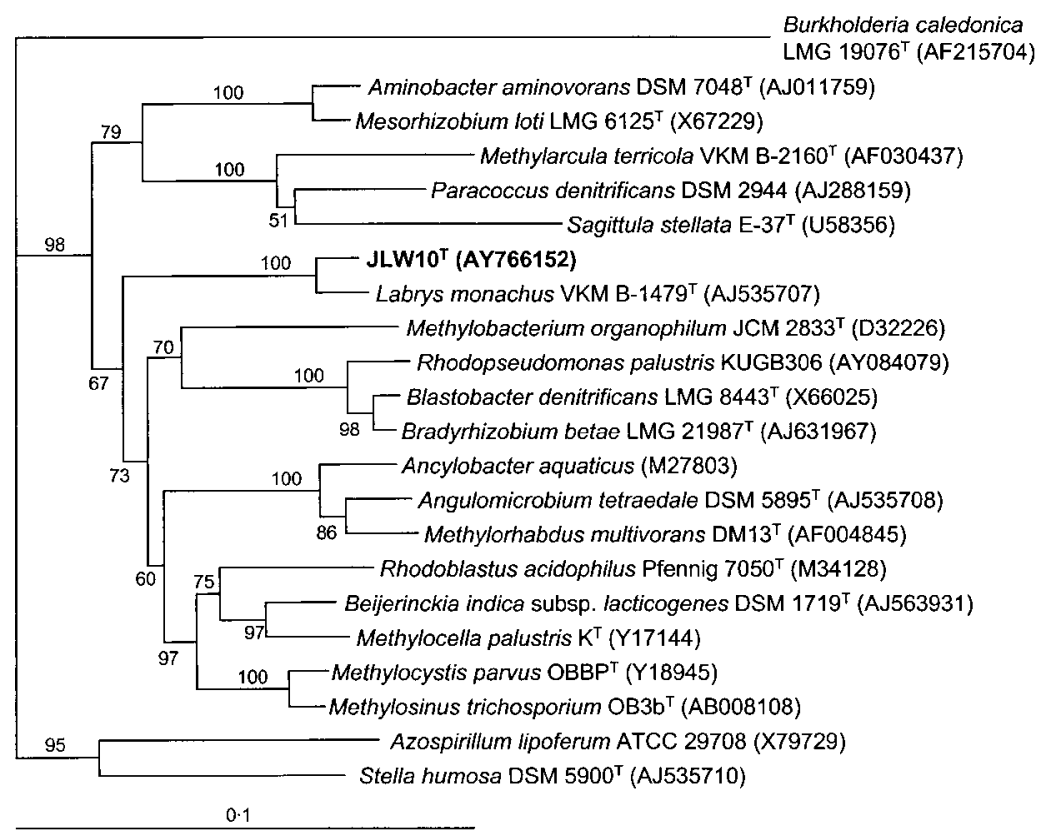

Fig. 2. $16 \mathrm{~S}$ rRNA gene-based phylogenetic tree (neighbour-joining) showing the position of strain $\mathrm{JLW}_{10} 0^{\top}$ in relation to methylotrophic and non-methylotrophic $\alpha$-proteobacteria. Bootstrap values (\%) are shown at nodes. The sequence from Burkholderia caledonica LMG $19076^{\top}$ was used as the outgroup. Bar, 10\% sequence divergence. 
group and span the $\alpha-, \beta$ - and $\gamma$-subclasses of Proteobacteria. Within the $\alpha$-subclass, at least 12 genera are classified that include well-characterized methylotrophic species: Hyphomicrobium, Methylobacterium, Aminobacter, Methylorhabdus, Methylarcula, Methylopila, Xanthobacter, Paracoccus, Rhodopseudomonas, 'Methylosulfonomonas', Ancylobacter and Albibacter. However, the ability to grow on a variety of reduced single-carbon $\left(\mathrm{C}_{1}\right)$ substrates is even more widespread, since some bacteria capable of growth on $\mathrm{C}_{1}$ compounds have never been classified as methylotrophs. For example, $\mathrm{C}_{1}$ growth has been reported for bacteria involved in polymer transformation, such as Sagittula stellata (Gonzalez et al., 1997), or oligotrophic budding bacteria such as Angulomicrobium (Fritz et al., 2004).

Isolate $\mathrm{JLW} 10^{\mathrm{T}}$, as described here, is another representative of heterotrophic bacteria with a broad range of metabolic capacities. Even though originally isolated as a dominant culture in methylamine enrichments, this bacterium is capable of growth on a variety of organic substrates, including polymers such as agarose and humic acids. Of all characterized bacteria, isolate JLW $10^{\mathrm{T}}$ is most related to L. monachus (Vasil'eva \& Semenov, 1984; Fritz et al., 2004). Based on genotypic analysis, both bacteria are clearly separated from all known taxa and form a distinct branch within the $\alpha$-subclass of Proteobacteria. However, the low DNA-DNA relatedness and the unique fatty acid profile of isolate JLW $10^{\mathrm{T}}$ separate it from L. monachus. The dominance of $\mathrm{C}_{19: 0}$ cyclo fatty acid $(49 \cdot 4 \%)$ is a distinctive feature of this isolate that will potentially become a signature for this bacterium at the species level. Based on comparative analysis of JLW $10^{\mathrm{T}}$ with other representative genera and species, we propose that isolate $\mathrm{JLW} 10^{\mathrm{T}}$ represents a novel species within the genus Labrys. The species name proposed for isolate JLW $10^{\mathrm{T}}$, Labrys methylaminiphilus, reflects the propensity of this strain to grow on methylamine and the history of its enrichment and isolation.

\section{Description of Labrys methylaminiphilus sp. nov.}

Labrys methylaminiphilus (me.thy'la.mi.ni.phi'lus. N.L. n. methyl the methyl radical; N.L. n. amini the amine group; Gr. adj. philos loving; N.L. masc. adj. methylaminiphilus methylamine-loving, referring to the methylamine-utilizing activity of the bacterium).

Cells are Gram-negative, non-motile, non-spore-forming, capsulated, multiply by budding and are oxidase- and catalase-positive. Growth is aerobic but may be microaerophilic. Grows on methylamine, dimethylamine and trimethylamine as sole sources of energy and carbon. Methylamine is oxidized to formaldehyde via the N-MG pathway. Carbon is assimilated via the serine cycle. Other substrates supporting growth include a wide range of sugars, organic acids, amino acids, aromatic compounds and alcohols. Nitrogen sources include methylated amines, most amino acids, urea, peptone, ammonium salts and nitrates. No additional growth factors are required, but yeast extract has a stimulatory effect. The major components of the fatty acid profile are $\mathrm{C}_{18: 1} \omega 7 c, \mathrm{C}_{19: 0}$ cyclo and $\mathrm{C}_{16: 0}$. The major phospholipids are phosphatidyl acid, phosphatidylcholine and phosphatidylethanolamine. The $\mathrm{G}+\mathrm{C}$ content of the DNA is $65 \cdot 7 \pm 0 \cdot 3 \mathrm{~mol} \%$. Cells are $0 \cdot 7-1 \cdot 0 \mu \mathrm{m}$ wide and $1 \cdot 0-1 \cdot 2 \mu \mathrm{m}$ long. The temperature range for growth is $10-35^{\circ} \mathrm{C}$, with optimal growth at $28-30{ }^{\circ} \mathrm{C}$. The $\mathrm{pH}$ range is $4 \cdot 0-9 \cdot 5$, with optimal $\mathrm{pH}$ at $5 \cdot 0-7 \cdot 0$. Does not produce indole and the Voges-Proskauer test is negative. No water-soluble fluorescent pigments are produced on King B medium. Oxidase and catalase activities are present, but not urease activity.

The type strain, JLW10 ${ }^{\mathrm{T}}$ (=ATCC BAA-1080 ${ }^{\mathrm{T}}=\mathrm{DSM}$ $\left.16812^{\mathrm{T}}\right)$, was isolated from the sediment of Lake Washington, Seattle, WA, USA.

\section{Acknowledgements}

This research was supported by a grant to M. E. L. and L. C. from the National Science Foundation Microbial Observatories Program (MCB0131957). We are grateful to the crew of the RV Clifford Barnes and to Dr S. Stolyar for their help with sample acquisition.

\section{References}

Anthony, C. (1982). Biochemistry of Methylotrophs. London: Academic Press.

Anthony, C. \& Zatman, L. J. (1965). The microbial oxidation of methanol. The alcohol dehydrogenase of Pseudomonas sp. M27 Biochem J 96, 808-812.

Auman, A. J., Stolyar, S., Costello, A. M. \& Lidstrom, M. E. (2000). Molecular characterization of methanotrophic isolates from freshwater lake sediment. Appl Environ Microbiol 66, 5259-5266.

Costello, A. M. \& Lidstrom, M. E. (1999). Molecular characterization of functional and phylogenetic genes from natural populations of methanotrophs in lake sediments. Appl Environ Microbiol 65, 5066-5074

Daniels, L., Hanson, R. S. \& Philips, J. A. (1994). Chemical analysis. In Methods for General and Molecular Bacteriology, pp. 512-554. Edited by P. Gerhardt, R. G. E. Murray, W. A. Wood \& N. R. Krieg. Washington, DC: American Society for Microbiology.

Dawson, R. M. C., Elliott, D. C., Elliott, W. H. \& Jones, K. M. (2002). Data for Biochemical Research. New York: Oxford University Press.

De Marco, P., Pacheco, C. C., Figueiredo, A. R. \& Moradas-Ferreira, P. (2004). Novel pollutant-resistant methylotrophic bacteria for use in bioremediation. FEMS Microbiol Lett 234, 75-80.

Dittmer, J. C. \& Wells, M. A. (1969). Quantitative and qualitative analysis of lipids and lipid components. Methods Enzymol 14, 482-530.

Doronina, N. V., Braus-Strohmeyer, S. A., Leisinger, T. \& Trotsenko, Y. A. (1995). Isolation and characterization of a new facultatively methylotrophic bacterium: description of Methylorhabdus multivorans gen. nov., sp. nov. Syst Appl Microbiol 18, 92-98.

Doronina, N. V., Trotsenko, Y. A., Krausova, V. I., Boulygina, E. S. \& Tourova, T. P. (1998). Methylopila capsulata gen. nov., sp. nov., a novel non-pigmented aerobic facultatively methylotrophic bacterium. Int J Syst Bacteriol 48, 1313-1321. 
Doronina, N. V., Trotsenko, Y. A. \& Tourova, T. P. (2000). Methylarcula marina gen. nov., sp. nov. and Methylarcula terricola sp. nov.: novel aerobic, moderately halophilic, facultatively methylotrophic bacteria from coastal saline environments. Int J Syst Evol Microbiol 50, 1849-1859.

Eady, R. R. \& Large, P. J. (1968). Purification and properties of an amine dehydrogenase from Pseudomonas AM1 and its role in growth on methylamine. Biochem J 106, 245-255.

Felsenstein, J. (2003). Inferring Phylogenies. Sunderland, MA: Sinauer Associates.

Fritz, l., Strömpl, C. \& Abraham, W. R. (2004). Phylogenetic relationships of the genera Stella, Labrys and Angulomicrobium within the 'Alphaproteobacteria' and description of Angulomicrobium amanitiforme sp. nov. Int J Syst Evol Microbiol 54, 651-657.

Gonzalez, J. M., Mayer, F., Moran, M. A., Hodson, R. E. \& Whitman, W. B. (1997). Sagittula stellata gen. nov., sp. nov., a lignintransforming bacterium from a coastal environment. Int $J$ Syst Bacteriol 47, 773-780.

Goodwin, P. (1990). Assay of assimilatory enzymes in crude extracts of serine pathway methylotrophs. Methods Enzymol 188, 361-365.

Harder, W., Attwood, M. \& Quayele, J. R. (1973). Methanol assimilation by Hyphomicrobium spp. J Gen Microbiol 78, 155-163.

Holmes, A. J., Kelly, D. P., Baker, S. C., Thompson, A. S., De Marco, P., Kenna, E. M. \& Murrell, J. C. (1997). Methylosulfonomonas methylovora gen. nov., sp. nov., and Marinosulfonomonas methylotropha gen. nov., sp. nov.: novel methylotrophs able to grow on methanesulfonic acid. Arch Microbiol 167, 46-53.

Johnson, J. L. (1994). Similarity analysis of DNAs. In Methods for General and Molecular Bacteriology, pp. 655-681. Edited by P. Gerhardt, R. G. E. Murray, W. A. Wood \& N. R. Krieg. Washington, DC: American Society for Microbiology.

Kämpfer, P., Neef, A., Salkinoja-Salonen, M. S. \& Busse, H.-J. (2002). Chelatobacter heintzii (Auling et al. 1993) is a later subjective synonym of Aminobacter aminovorans (Urakami et al. 1992). Int $J$ Syst Evol Microbiol 52, 835-839.

Kimura, T., Sugahara, I., Hanai, K. \& Asahi, T. (1995). Purification and characterization of the new $\gamma$-glutamylmethylamide dissimilating enzyme system from Methylophaga sp. AA-30. Biosci Biotechnol Biochem 59, 648-655.

Kuivila, K. M., Murray, J. W., Devol, A. H., Lidstrom, M. E. \& Reimers, C. E. (1988). Methane cycling in the sediments of Lake Washington. Limnol Oceanogr 33, 571-581.

Lane, D. J. (1991). 16S/23S rRNA sequencing. In Nucleic Acid Techniques in Bacterial Systematics, pp. 115-175. Edited by E. Stackebrandt \& M. Goodfellow. New York: Wiley.

McDonald, I. R. \& Murrell, J. C. (1997). The methanol dehydrogenase structural gene $m x a F$ and its use as a functional gene probe for methanotrophs and methylotrophs. Appl Environ Microbiol 63, $3218-3224$.
Murray, R. G. E. (1992). The family Deinococcaceae. In The Prokaryotes, 2nd edn, pp. 3732-3744. Edited by A. Balows, H. G. Trüper, H. Dworkin, W. Harder \& K. H. Schleifer. New York: Springer.

Pol, A., Op den Camp, H. J., Mees, S. G., Kersten, M. A. \& van der Drift, C. (1994). Isolation of a dimethylsulfide-utilizing Hyphomicrobium species and its application in biofiltration of polluted air. Biodegradation 5, 105-112.

Sambrook, J., Fritsch, E. F. \& Maniatis, T. (1989). Molecular Cloning: a Laboratory Manual, 2nd edn. Cold Spring Harbor, NY: Cold Spring Harbor Laboratory.

Shishkina, V. N., lurchenko, V. V., Romanovskaia, V. A., Malashenko, lu. R. \& Trotsenko, lu. A. (1976). Alternativity of methane assimilation pathways in obligate methylotrophs. Mikrobiologiia 45, 417-419 (in Russian).

Smibert, R. M. \& Krieg, N. R. (1994). Phenotypic characterization. In Methods for General and Molecular Bacteriology, pp. 611-654. Edited by P. Gerhardt, R. G. E. Murray, W. A. Wood \& N. R. Krieg. Washington, DC: American Society for Microbiology.

Tabita, F. R. (1980). Pyridine nucleotide control and subunit structure of phosphoribulokinase from photosynthetic bacteria. $J$ Bacteriol 143, 1275-1280.

Tamaoka, J. \& Komagata, K. (1984). Determination of DNA base composition by reversed-phase high-performance liquid chromatography. FEMS Microbiol Lett 25, 125-128.

Thompson, J. D., Higgins, D. G. \& Gibson, T. J. (1994). CLUSTAL W: improving the sensitivity of progressive multiple sequence alignment through sequence weighting, position-specific gap penalties and weight matrix choice. Nucleic Acids Res 22, 4673-4680.

Vasil'eva, L. V. \& Semenov, A. M. (1984). New budding prosthecate bacterium Labrys monahos with radial cell symmetry. Microbiology (English translation of Mikrobiologiia) 53, 68-75.

Vorholt, J. A., Chistoserdova, L., Lidstrom, M. E. \& Thauer, R. K. (1998). The NADP-dependent methylene tetrahydromethanopterin dehydrogenase in Methylobacterium extorquens AM1. J Bacteriol 180, 5351-5356.

Vorholt, J. A., Chistoserdova, L., Stolyar, S. M., Thauer, R. K. \& Lidstrom, M. E. (1999). Distribution of tetrahydromethanopterindependent enzymes in methylotrophic bacteria and phylogeny of methenyl tetrahydromethanopterin cyclohydrolases. J Bacteriol 181, 5750-5757.

Vorholt, J. A., Marx, C. J., Lidstrom, M. E. \& Thauer, R. K. (2000). Novel formaldehyde-activating enzyme in Methylobacterium extorquens AM1 required for growth on methanol. J Bacteriol 182, 6645-6650.

White, D. C., Davis, W. M., Nickels, J. S., King, J. D. \& Bobbie, R. J. (1979). Determination of the sedimentary microbial biomass by extractable lipid phosphate. Oecologia 40, 51-62.

Zehr, J. P. \& McReynolds, L. A. (1989). Use of degenerate oligonucleotides for amplification of the nifH gene from the marine cyanobacterium Trichodesmium thiebautii. Appl Environ Microbiol 55, 2522-2526. 